\title{
Monetary Policy in Small Open Economies: The Role of Exchange Rate Rules
}

\author{
Ana Maria Santacreu
}

\begin{abstract}
Understanding the costs and benefits of alternative monetary policy rules is important for economic welfare. Within the context of a small open economy model and building on the work of Mihov and Santacreu (2013), the author analyzes the economic implications of two monetary policy rules. The first is a rule in which the central bank uses the nominal exchange rate as its policy instrument and adjusts the rate whenever there are changes in the economic environment. The second is a standard interest rate rule in which the central bank adjusts the short-term nominal interest rate to changes in the economic environment. The main finding of the analysis is that, if the uncovered interest parity condition that establishes a tight link between the interest rate differential in two countries and the expected rate of depreciation of their currencies does not hold, the exchange rate rule outperforms the standard interest rate rule in lowering the volatility of key economic variables. There are two main reasons for this: First, the actual implementation of the exchange rate rule avoids the overshooting effect on exchange rates characteristic of an interest rate rule. And second, the risk premium that generates deviations from the uncovered interest parity condition is smaller and less volatile under an exchange rate rule. (JEL E52, E58, F41)
\end{abstract}

Federal Reserve Bank of St. Louis Review, Third Quarter 2015, 97(3), pp. 217-32.

Ana Maria Santacreu is an economist at the Federal Reserve Bank of St. Louis. This article is based on a research project with llian Mihov entitled "The Exchange Rate as an Instrument of Monetary Policy." The author thanks Fernando Leibovici, Ilian Mihov, Paulina Restrepo-Echevarria, Yi Wen, and Steve Williamson for helpful comments and Usa Kerdnunvong for research assistance.

○ 2015, Federal Reserve Bank of St. Louis. The views expressed in this article are those of the author(s) and do not necessarily reflect the views of the Federal Reserve System, the Board of Governors, or the regional Federal Reserve Banks. Articles may be reprinted, reproduced, published, distributed, displayed, and transmitted in their entirety if copyright notice, author name(s), and full citation are included. Abstracts, synopses, and other derivative works may be made only with prior written permission of the Federal Reserve Bank of St. Louis. 
prefer to maintain tight control over the exchange rate. Several authors have analyzed the performance of monetary rules that explicitly take into account the exchange rate in the context of general equilibrium models. In particular, two exchange rate situations have been analyzed: (i) flexible exchange rates in which the monetary authority follows an extended IRR that reacts to deviations of inflation, output, and the exchange rate (De Paoli, 2009) or (ii) fixed exchange rates in which the central bank pegs the exchange rate to the currency of another country and commits to defending such a peg by losing its ability to control the nominal interest rate (Schmitt-Grohé and Uribe, 2011). The United States, Canada, and Japan, for instance, follow a flexible exchange rate regime. Hong Kong, Denmark, and Bulgaria follow a fixed exchange rate regime.

There is a third possibility that has not been analyzed extensively in the context of a general equilibrium model. The central bank could use the exchange rate as an instrument in the same way it uses the interest rate in the IRR — that is, by adjusting the exchange rate to fluctuations in economic conditions. This is known as an exchange rate rule (ERR) and is the policy followed by the Monetary Authority of Singapore (MAS) since 1981. Indeed, 98 percent of the assets held on the MAS balance sheet are foreign assets. Therefore, in contrast to other small open economies in which the central bank intervenes mainly in the domestic bond market to conduct monetary policy while still paying attention to fluctuations in the nominal exchange rate (as in New Zealand, Australia, and Canada), the MAS intervenes mainly in the foreign exchange market to conduct monetary policy. (This scenario differs from situation (i) mentioned earlier.) Thus, their instrument is the nominal effective exchange rate, which is allowed to fluctuate whenever there are changes in economic conditions. (This scenario differs from situation (ii) mentioned earlier.)

In a recent article, Mihov and Santacreu (2013) attempt to fill this gap in the literature by analyzing a small open economy model of monetary policy to compare the implications of two types of rules for economic volatility. First, they examine a model in which the central bank uses the short-term nominal interest rate as the instrument and allows the exchange rate to adjust from the decisions of economic agents (IRR). Then, they study a model in which the central bank uses the exchange rate as the instrument and allows the interest rate to adjust from the decisions of economic agents (ERR). They ask the following question: Under what conditions can a central bank achieve lower economic volatility by using an ERR rather than an IRR?

Mihov and Santacreu (2013) argue that the costs and benefits of an IRR versus those of an ERR depend on two factors: the actual implementation of the policy and whether the uncovered interest parity (UIP) condition holds. First, the actual implementation of the rule is important. While the central bank technically can replicate any IRR by moving the exchange rate today and announcing depreciation consistent with UIP, this is not how the rule operates.

In Mihov and Santacreu (2013), the exchange rate today is predetermined and the central bank announces the depreciation rate from time $t$ to $t+1$. This implies, for example, that the model may not feature the standard overshooting result as the currency rate both today and at $t+1$ are determined by the monetary authority. However, they find this feature is insufficient in generating significant differences between the two rules. Therefore, the only way the 
new model can provide interesting dynamics is by incorporating a failure of UIP. UIP predicts that currencies with high interest rates will depreciate relative to those with low interest rates. That is, arbitrage should ensure that the following two investment strategies are equivalent: An investor either buys a domestic asset at the current domestic interest rate and collects the proceedings tomorrow or exchanges domestic currency for foreign currency at the current exchange rate to invest in an identical foreign asset that pays the interest rate of the foreign country and tomorrow exchanges the foreign currency back to domestic currency. This strategy implies that if the domestic interest rate is higher than the foreign interest rate, one should expect the domestic currency to depreciate between today and tomorrow.

Alvarez, Atkeson, and Kehoe (2007) argue that in large part the impact of monetary policy on the economy proceeds through conditional variances of macroeconomic variables rather than conditional means. In terms of the UIP condition, their article implies that the interest parity condition has a time-varying risk premium. Interest in time-varying risk premiums has been growing in recent years. In the context of the interest parity condition, Verdelhan (2010) shows how consumption models with external habit formation can generate a countercyclical risk premium that matches key stylized facts quite successfully. Mihov and Santacreu (2013) adopt a similar approach by allowing external habit formation in consumption.

In a production economy, Mihov and Santacreu (2013) find that an ERR achieves lower volatility of both nominal and real variables. Contrary to a fixed exchange rate scenario in which the central bank achieves lower volatility of nominal variables at the expense of increasing the volatility of the real variables (Schmitt-Grohé and Uribe, 2011), an ERR can stabilize both because it is an intermediate exchange rate regime. The reasons are twofold: First, the actual implementation of the policy avoids the overshooting effect of an IRR. Second, an ERR reduces the mean and the volatility of the risk premium that causes deviations from UIP.

The article proceeds as follows. First, I describe how an ERR operates and use the case of Singapore to illustrate it. Then, I present an endowment economy that features deviations from UIP through the existence of a risk premium. I show that the risk premium responsible for these deviations depends on the particular policy rule the central bank follows (IRR versus ERR) and the parameters of the monetary policy rule. In an endowment economy, these deviations affect only nominal variables. To capture the effect of alternative rules on both nominal and real variables, I then describe a small open production economy in which consumption and output are both endogenous and report the quantitative implications of the model.

\section{EXCHANGE RATE RULES: SINGAPORE}

In this section, I describe Singapore's monetary policy to illustrate how an ERR works. According to the MAS Act, the main objective of monetary policy in Singapore is "to ensure low inflation as a sound basis for sustained economic growth" (Monetary Authority of Singapore). To do that, since 1981,

The MAS manages the Singapore dollar ( $\$$ ) exchange rate against a trade-weighted basket of currencies of Singapore's major trading partners and competitors. The composition of this basket is reviewed and revised periodically to take into account changes in Singapore's 


\section{Figure 1}

\section{Singapore Dollar Nominal Effective Exchange Rate}

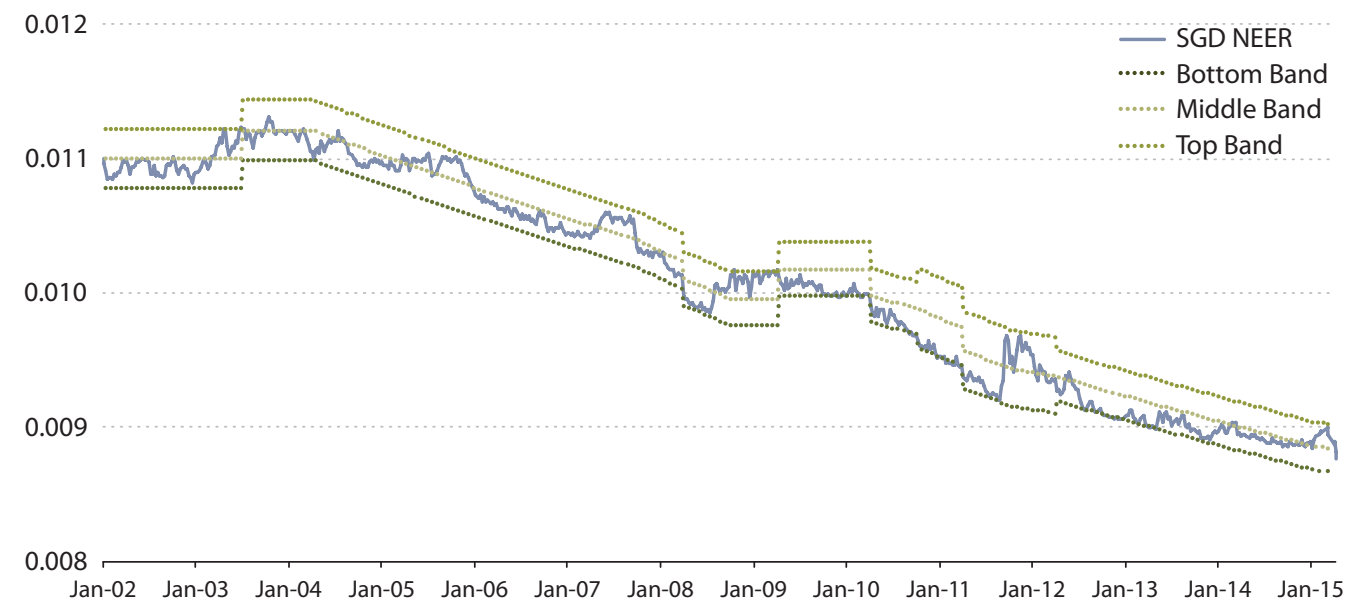

NOTE: Here, the Singapore dollar (SGD) nominal effective exchange rate (NEER) is defined as the inverse of the usual NEER and in terms of trade-weighted trading partners' currencies per the Singapore dollar. Thus, the decrease in the figure means an appreciation of the Singapore dollar currency. The bottom, middle, and top band indexes are estimated by Citigroup, based on MAS monetary policy statements.

SOURCE: Calculations based on: Citi Research, SGD NEER Indices, Bloomberg Finance L.P; accessed April 2015.

trade patterns. This trade-weighted exchange rate is maintained broadly within an undisclosed target band, and is allowed to appreciate or depreciate depending on factors such as the level of world inflation and domestic price pressures. MAS may also intervene in the foreign exchange market to prevent excessive fluctuations in the $S \$$ exchange rate.

In the context of Singapore's open capital account, the choice of the exchange rate as the focus of monetary policy would necessarily imply that domestic interest rates and money supply are endogenous. As such, MAS's money market operations are conducted mainly to ensure that sufficient liquidity is present in the banking system to meet banks' demand for reserve and settlement balances. (Monetary Authority of Singapore)

Specifically, the MAS announces a path of appreciation or depreciation of its currency based on the expected economic conditions. Figure 1 shows Singapore's nominal exchange rate with respect to a basket of currencies since January 2002. As the downward trend reveals, the Singapore dollar has been appreciating over time, which reflects Singapore's rapid economic development during this time. (The definition of the exchange rate in the figure is such that a decrease implies an appreciation of the Singapore dollar.) In the short run, the exchange rate fluctuates. To avoid misalignment and deviations from the fundamentals, the MAS intervenes in the foreign exchange market to keep the value of the exchange rate within a specified policy band. The monetary authority may change the slope of the band when changes in the economic environment call for it. As Figure 1 shows, the MAS has changed the slope of appreciation of 


\section{Table 1}

\section{Reaction Function}

\begin{tabular}{cccc}
$\begin{array}{c}\text { Constant } \\
(\alpha)\end{array}$ & $\begin{array}{c}\text { Inflation } \\
\left(\widehat{\phi_{\pi}}\right)\end{array}$ & $\begin{array}{c}\text { Output gap } \\
\left(\widehat{\phi_{y}}\right)\end{array}$ & $\begin{array}{c}\text { Lagged appreciation } \\
(\rho)\end{array}$ \\
\hline-0.379 & $0.288^{* *}$ & $0.276^{* *}$ & $0.744^{* * *}$ \\
$(0.291)$ & $(0.120)$ & $(0.130)$ & $(0.052)$
\end{tabular}

NOTE: Standard errors are shown in parentheses. ${ }^{* *}$ and ${ }^{* * *}$ denote significance at the 5 percent and 1 percent levels, respectively.

SOURCE: Mihov (2013). Used with permission.

the instrument several times. The most recent intervention was in January 2015, when the MAS slowed the rate of appreciation of the Singapore dollar. ${ }^{3}$

Several authors (see, for example, Parrado, 2004) have estimated a reaction function for changes in the monetary policy instrument as proxied by the change in the nominal exchange rate. Traditional empirical reaction functions have used the nominal interest rate as the instrument. Monetary policy in Singapore is unique in that it uses the nominal exchange rate to achieve low inflation and sustained growth. In particular, assume (i) that the monetary authority has a target for the change in the nominal exchange rate $\Delta e_{t}^{*}$ and (ii) that it adjusts the target based on deviations of inflation from a prespecified target and deviations of output from its potential level as follows:

$$
\Delta e_{t}^{*}=\Delta \bar{e}-\phi_{\pi}\left(\pi_{t}-\pi^{*}\right)-\phi_{y}\left(y_{t}-y^{*}\right),
$$

where $\Delta \bar{e}$ is the long-run equilibrium change in the nominal exchange rate consistent with long-run purchasing power parity, $\pi_{t}$ is the inflation rate at time $t, \pi^{*}$ is a target for inflation, $y_{t}$ is the level of output, and $y^{*}$ is the potential level of output the economy would produce if all the factors of production were fully employed (i.e., $y_{t}-y^{*}$ is the output gap). Consistent with the definition of the nominal effective exchange rate in Figure 1, an increase in the nominal exchange rate in the equation represents a depreciation of the Singapore dollar. I follow this convention throughout the article.

To capture some degree of smoothing in the adjustment of the nominal exchange rate to its target level,

$$
\Delta e_{t}=\left(1-\rho_{e}\right) \Delta e_{t}^{*}+\rho_{e} \Delta e_{t-1},
$$

where $\rho_{e} \in[0,1]$ is the degree of exchange rate smoothing.

Combining the two previous expressions yields the following equation:

$$
\Delta e_{t}=\alpha-\widehat{\phi_{\pi}}\left(\pi_{t}-\pi^{*}\right)-\widehat{\phi_{y}}\left(y_{t}-y^{*}\right)+\rho \Delta e_{t-1},
$$


where $\alpha$ is a constant, $\widehat{\phi_{\pi}}=\phi_{\pi}\left(1-\rho_{e}\right)$, and $\widehat{\phi_{y}}=\phi_{y}\left(1-\rho_{e}\right)$. Table 1 reports the results from the estimation of the previous expression. ${ }^{4}$

Table 1 shows that the Singapore dollar appreciates when inflation increases or the output gap widens. In particular, a 1 percent increase in inflation implies a 0.288 percent appreciation in the Singapore dollar. Similarly, a 1 percent increase in the output gap implies a 0.276 percent appreciation in the Singapore dollar. The estimation also shows some degree of exchange rate smoothing, with an estimated smoothing parameter of 0.744 .

\section{MONETARY POLICY AND THE UNCOVERED INTEREST PARITY CONDITION: AN ENDOWMENT ECONOMY}

Next, I present a model that captures deviations from UIP by introducing an endogenous risk premium on foreign-denominated assets. I start with an endowment economy so that I can derive an analytical expression for the risk premium. The economy is a small open economy in which there is a representative consumer who maximizes a utility function that features external habit in consumption. Consumption follows an exogenous process, and there are complete international markets. Inflation is determined by a central bank that uses either the nominal interest rate (the IRR) or the exchange rate (the ERR) as its instrument. I assume that, in the rest of the world, the central bank follows an IRR, since it behaves as a closed economy and is not as strongly affected by fluctuations in the nominal exchange rate as the small open economy.

After deriving an analytical solution for the risk premium under both monetary policy rules (an IRR and an ERR), I show that the risk premium responsible for deviations from UIP depends on the particular monetary rule followed by the central bank and the parameters of the rule-that is, on the magnitude of the central bank's reaction to fluctuations in inflation and the output gap.

\section{Theory}

Standard asset-pricing models assume that the UIP condition holds. That is, the models predict that high interest rate currencies will depreciate relative to low interest rate currencies to satisfy an arbitrage condition. However, for many currency pairs and time periods, the opposite seems to occur (Fama, 1984). In the literature, the inability of asset-pricing models to reproduce the empirical evidence is referred to as the UIP puzzle. The UIP evidence is related to short-term interest rates and currency depreciation rates. Because monetary policy influences short-term interest rates in the case of an IRR or nominal exchange rates in the case of an ERR, the UIP puzzle can be formulated in terms of monetary policy (Backus et al., 2010). A traditional open economy model cannot replicate the forward premium anomaly as it typically assumes that UIP holds. When investors are assumed to be risk neutral, any cross-country differences in interest rates are associated with offsetting movements in expected depreciation. Various approaches in the literature to account for the forward premium anomaly include assuming that markets are incomplete (Benigno, 2009) and modeling the deviations through 
a risk premium that generates a wedge between the interest rate differential and the expected exchange rate depreciation (Alvarez, Atkeson, and Kehoe, 2009; Backus et al., 2010; Benigno, Benigno, and Nisticò, 2013; and Verdelhan, 2010, among others). The risk premium interpretation of the UIP puzzle asserts that high interest rate currencies pay positive risk premiums.

Therefore, one could derive an expression for the risk premium that depends on the monetary policy instrument and ask the following question: What monetary policy generates larger fluctuations of the risk premium and therefore larger deviations from the UIP condition? To answer this question, I derive an analytical solution for the foreign exchange risk premium as a function of the monetary rule parameters for both an IRR and an ERR. I follow the procedure described by Backus et al. (2010) for an endowment economy with complete markets but with one modification: Instead of using recursive preferences, I assume there is external habit in the utility function (as in Verdelhan, 2010). External habit formation, also known as "catching up with the Joneses" (Abel, 1990), simplifies the consumer's optimization problem because the evolution of the stock of habit is taken as exogenous by the consumer.

The following steps are taken to obtain an expression for the risk premium:

Step 1: Preferences. In each country, there is a representative household that maximizes lifetime expected utility. The utility function of the household in the domestic economy is given by

$$
E_{0} \sum_{t=0}^{\infty} \beta^{t} U\left(C_{t}-h X_{t}\right)=\frac{\left(C_{t}-h X_{t}\right)^{1-\gamma}}{1-\gamma},
$$

where $\gamma$ denotes the coefficient of risk aversion, $h$ is the parameter of habit persistence, $X_{t}$ is the level of habits defined below, and $C_{t}$ is consumption.

The evolution of habits follows an $\operatorname{AR}(1)$ process with accumulation of habits based on last-period consumption:

$$
X_{t}=\delta X_{t-1}+(1-\delta) C_{t-1},
$$

where $\delta \in[0,1]$ captures the degree of habit persistence.

In a model with habit $(h \neq 0)$, the consumer cares about deviations of consumption from a certain subsistence level. In this case, the coefficient of relative risk aversion (CRRA) is

$$
\text { CRRA }_{t}:=\frac{\gamma C_{t}}{C_{t}-h X_{t}}
$$

The CRRA is time varying and countercyclical: In good times, when consumption is far from its subsistence level (i.e., $C_{t}>h X_{t}$ ), the denominator increases and risk aversion decreases. Good times correspond to a positive shock to consumption growth.

Following the literature, assume that the log of consumption follows the $\mathrm{AR}(1)$ process

$$
\log \left(C_{t+1}\right)=\lambda \log \left(C_{t}\right)+\varepsilon_{c, t+1},
$$

where $\lambda \in[0,1]$ and $\varepsilon_{c, t+1}$ is an i.i.d. process with zero mean and standard deviation $\sigma_{\varepsilon}$.

Step 2: The Stochastic Discount Factor. In this economy, the stochastic discount factor or pricing kernel is determined by the following expression: 


$$
M_{t, t+1}=\beta \frac{U_{c}\left(C_{t+1}-h X_{t+1}\right)}{U_{c}\left(C_{t}-h X_{t}\right)}=\beta\left(\frac{C_{t+1}-h X_{t+1}}{C_{t}-h X_{t}}\right)^{-\gamma} .
$$

Step 3: The Risk-Free Rate. Define the risk-free rate $R_{t}$ as

$$
R_{t}=\frac{1}{E_{t}\left(M_{t, t+1}\right)}
$$

where $R_{t}$ is the gross return on a riskless, one-period discount bond paying off one unit of domestic currency in $t+1$.

The Euler equation of a foreign investor buying a foreign bond with return $R_{t+1}^{*}$ is

$$
E_{t}\left(M_{t, t+1}^{*} R_{t}^{*}\right)=1 \text {. }
$$

The Euler equation for a domestic investor buying the same foreign bond is

$$
E_{t}\left(M_{t, t+1} R_{t}^{*} \frac{Q_{t+1}}{Q_{t}}\right)=1,
$$

where $Q_{t}$ is the real exchange rate expressed as the amount of domestic good per unit of foreign good, defined as

$$
Q_{t}=e_{t} \frac{P_{t}^{*}}{P_{t}}
$$

where $P_{t}^{*}$ is the price of a basket of foreign goods and $P_{t}$ that of domestic goods. $M_{t, t+1}$ and $M_{t, t+1}^{*}$ are the domestic and foreign nominal pricing kernels, respectively.

Step 4: International Risk-Sharing Condition. Households have access to a complete set of contingent securities that are traded internationally-that is, markets are complete. With complete markets, the stochastic discount factor is unique and the following expression holds:

$$
\frac{Q_{t+1}}{Q_{t}}=\frac{M_{t, t+1}^{*}}{M_{t, t+1}} .
$$

We can now define the nominal interest differential $i_{t}-i_{t}^{*}$, where $i_{t}=\log \left(R_{t}\right)$ and $i_{t}^{*}=\log \left(R_{t}^{*}\right)$, the expected nominal depreciation is $\mathbb{E}_{t}\left[d e_{t+1}\right]$, and the exchange rate risk premium is $f x p_{t}$ in terms of the domestic and foreign nominal pricing kernels, $M_{t, t+1}$ and $M_{t, t+1}^{*}$, respectively. From the previous expressions we find that the interest rate differential has to equal the difference of the stochastic discount factors in the foreign and domestic economies:

$$
i_{t}-i_{t}^{*}=\log \left(\mathbb{E}_{t}\left[M_{t, t+1}^{*}\right]\right)-\log \left(\mathbb{E}_{t}\left[M_{t, t+1}\right]\right) \text {. }
$$

With complete markets,

$$
\mathbb{E}_{t}\left[d e_{t+1}\right]=\mathbb{E}_{t}\left[\log \left(M_{t, t+1}^{*}\right)\right]-\mathbb{E}_{t}\left[\log \left(M_{t, t+1}\right)\right] .
$$


Combining the previous two expressions and assuming log-normality of the pricing kernel, ${ }^{5}$

$$
i_{t}-i_{t}^{*}=\mathbb{E}_{t}\left[d e_{t+1}\right]+f x p_{t},
$$

with the risk premium defined as

$$
f x p_{t}=\frac{1}{2}\left[\operatorname{Var}_{t}\left[\log \left(M_{t, t+1}^{*}\right)\right]-\operatorname{Var}_{t}\left[\log \left(M_{t, t+1}^{*}\right)\right]\right] .
$$

The risk premium is equal to half the difference between the conditional variance of the foreign and domestic stochastic discount factors.

The risk premium in equation (9) captures deviations from UIP. In the absence of a risk premium, if the domestic interest rate were higher than the foreign interest rate, the domestic currency would be expected to depreciate over time such that an investor would be indifferent between holding a domestic or a foreign asset. However, with a positive risk premium, it is possible for high interest rate currencies to appreciate over time. This would happen if the investor were risk averse and would demand a positive premium to hold foreign currency.

Step 5: The Monetary Policy Rule. One can now derive an expression for the foreign risk premium when the domestic economy follows one of the two rules: an IRR or an ERR.

Assume that the foreign economy follows an IRR (because it is a large economy and therefore is not as strongly affected by exchange rate fluctuations as the small open economy):

$$
i_{t}^{*}=\phi_{\pi}^{*} \pi_{t}^{*}+\phi_{c}^{*} c_{t}^{*}
$$

where $i_{t}^{*}$ is the foreign nominal interest rate, $c_{t}^{*}$ is foreign consumption, and $\pi_{t}^{*}$ is foreign inflation.

In the domestic economy, we consider both IRR and ERR, as follows:

(i) IRR

$$
i_{t}=\phi_{\pi}^{I R R} \pi_{t}+\phi_{c}^{I R R} c_{t}
$$

The central bank increases the interest rate whenever inflation $\left(\pi_{t}\right)$ and consumption $\left(c_{t}\right)$ increase, with $\phi_{\pi}^{I R R}$ and $\phi_{c}^{I R R}$ indicating the magnitude of the adjustment.

(ii) ERR

$$
d e_{t}=-\phi_{\pi}^{E R R} \pi_{t}-\phi_{c}^{E R R} c_{t}
$$

The central bank appreciates the nominal exchange rate whenever inflation $\left(\pi_{t}\right)$ and consumption $\left(c_{t}\right)$ increase, with $\phi_{\pi}^{E R R}$ and $\phi_{c}^{E R R}$ indicating the magnitude of the adjustment.

Step 6: The Risk Premium. To derive an analytical solution for the risk premium, I follow Backus et al. (2010) and use the method of undetermined coefficients; they assume that inflation follows a particular functional form. Then, using the first-order conditions, the international risk-sharing condition, and the expression for the corresponding rule, I obtain an expression for the risk premium that can be expressed as 


\section{Table 2}

\section{Calibrated Parameters}

\begin{tabular}{lcc} 
Parameter & Description & Value \\
\hline$h$ & Habit & 0.85 \\
$\delta$ & Degree habit & 0.97 \\
$\gamma$ & Coefficient of risk aversion & 2.50 \\
$\lambda$ & Persistent shock & 0.01 \\
$\sigma_{\varepsilon}$ & Standard deviation shock & 2.50
\end{tabular}

SOURCE: Modified from Mihov and Santacreu (2013).

$$
f x p_{t}=\kappa_{0}-\kappa_{1} c_{t}-\kappa_{2} x_{t},
$$

where $x$ is the $\log$ of $X$ and $k_{0}>0, k_{1}>0$, and $k_{2}>0$ depend on the particular rule used and the parameters of the monetary policy rule (i.e., how strongly the central bank reacts to deviations of inflation from its target and fluctuations of the output gap). ${ }^{6}$

Note that the risk premium $f x p_{t}$ is time varying and countercyclical. In good times, when consumption is high, the risk premium decreases. It can also be shown that if $h=0$, then $k_{1}=k_{2}=0$, and there is a constant risk premium.

\section{Quantitative Results}

Now, I analyze the effect of the two alternative rules on the mean and volatility of the risk premium. Assuming a particular process for consumption growth in equation (2), one can use equation (13) to analyze the effect of the two policy rules on the deviations from UIP. Note that only the nominal variables are affected because consumption follows an exogenous process in this model.

Simulations of the endowment economy described previously show that the mean and the standard deviation of the risk premium differ depending on the particular rule followed by the monetary authority and the parameters of such a rule (i.e., how strongly the central bank reacts to deviations of inflation from its target and fluctuations of the output gap). Table 2 shows the calibrated parameters (see Mihov and Santacreu, 2013).

First, impulse response functions for a 1 percent standard deviation shock to consumption show that both consumption and inflation increase in the case of an IRR (the solid line in Figure 2). ${ }^{7}$ The central bank then increases the interest rate (see equation (11)), and the currency depreciates at $t+1$. If the UIP condition holds, the depreciation is exactly equal to the initial increase in the interest rate. However, because now there is a decrease in the risk premium (through equation (9)), the currency depreciates by less than it would with no risk premium.

In the case of an ERR (the dashed line in Figure 2), after a positive consumption growth the central bank reacts to the increase in both consumption and inflation by appreciating 


\section{Figure 2}

\section{Impulse Response Function to a Consumption Shock: ERR}
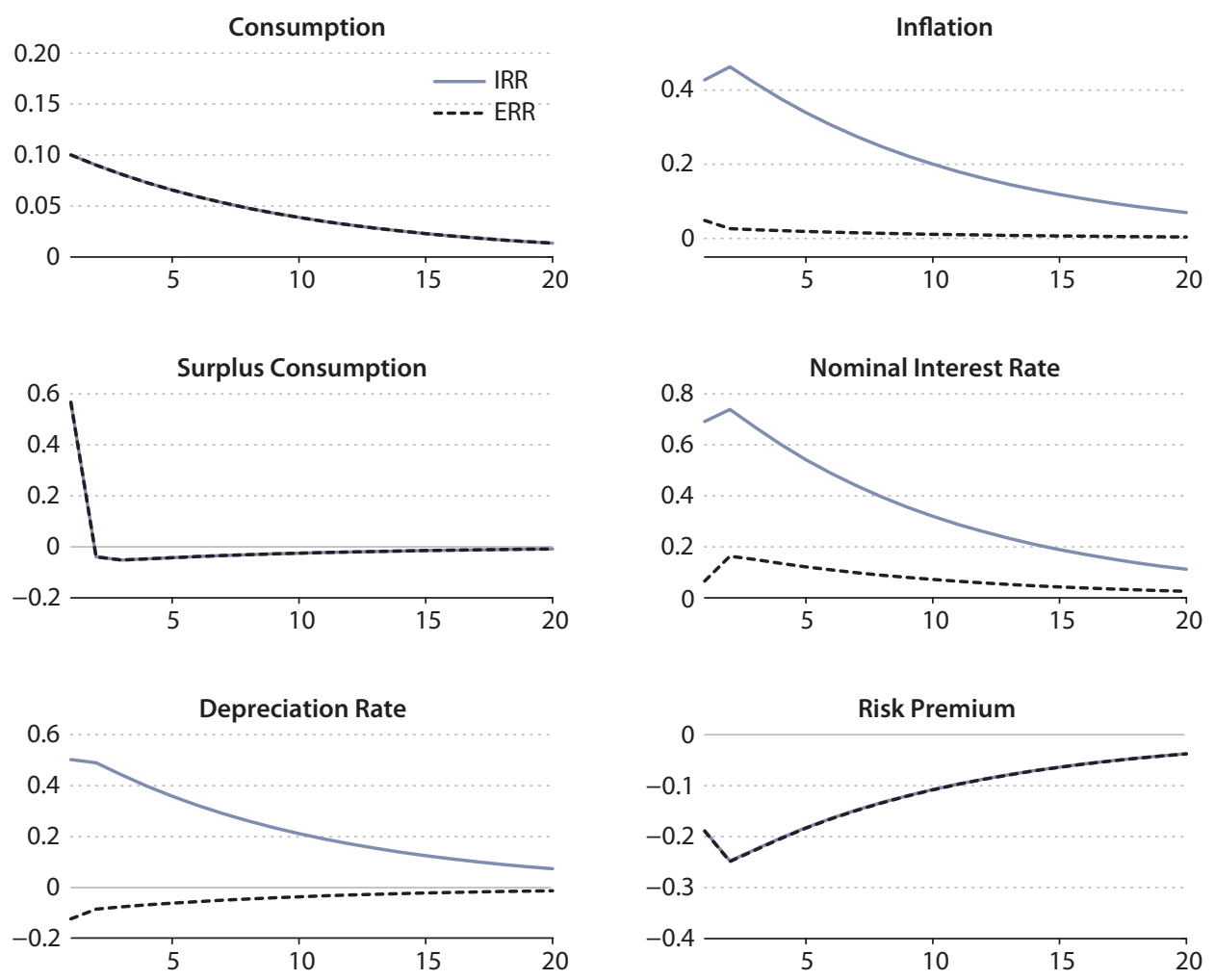

currency until it reaches a new equilibrium. If the UIP condition is satisfied, the interest rate should decrease by exactly the same amount, but the interest rate increases.

As Figure 2 shows, both inflation and the nominal interest rate respond less strongly to a consumption shock when the central bank follows an ERR than when it follows an IRR, which suggests that with an ERR the monetary authority is more successful in stabilizing the nominal variables. One of the main reasons is the actual implementation of the policy. The other is that the risk premium falls by less with an ERR than with an IRR.

The fall in the risk premium after a consumption shock has consequences on the differing effect of the two rules on the nominal variables. To better understand this point, Table 3 reports the mean and variance of the risk premium under each rule (IRR versus ERR) and for different values of the parameters of the reaction function $\left(\phi_{\pi}\right.$ and $\left.\phi_{c}\right)$. In all cases, the ERR delivers a lower mean and lower volatility in the risk premium. We also observe differences dependent on the magnitude of the monetary authority's reaction to fluctuations in inflation and consumption. These differences are more pronounced when the monetary authority follows an IRR. 
Santacreu

\section{Table 3}

Risk Premium

\begin{tabular}{|c|c|c|c|c|c|c|}
\hline \multirow[b]{2}{*}{ Parameter $\left(\phi_{\pi}, \phi_{c}\right)$} & \multicolumn{3}{|c|}{ IRR } & \multicolumn{3}{|c|}{ ERR } \\
\hline & $(1.5,0.5)$ & $(1.05,0.5)$ & $(1.50,0.05)$ & $(1.5,0.5)$ & $(1.05,0.5)$ & $(1.50,0.05)$ \\
\hline Mean & 4.293 & 10.680 & 3.985 & 2.850 & 2.880 & 2.915 \\
\hline Standard deviation & 0.633 & 0.644 & 0.632 & 0.629 & 0.629 & 0.629 \\
\hline
\end{tabular}

Because in this exercise I have modeled an endowment economy assuming the same consumption path under an IRR as under an ERR, the implied differences in the risk premium, although nonnegligible, are small and affect only nominal variables. To capture the effect of the different rules on real variables as well, one should consider a production economy in which consumption is endogenous and is also affected by the particular rule the monetary authority follows. In the next section, I describe a production economy version of the endowment economy just presented and analyze the effect of each rule on the volatility of economic variables.

\section{MONETARY POLICY AND THE UNCOVERED INTEREST PARITY CONDITION: A PRODUCTION ECONOMY}

Here I develop a production economy in which consumption growth is endogenous and depends on the particular monetary policy rule followed by the central bank. In contrast to the previous case of an endowment economy, now I cannot derive an analytical solution for the risk premium. However, the advantage of a production economy is that the monetary policy rule has a stronger effect on the risk premium, which generates larger differences between the two rules.

\section{Theory}

I follow the work of De Paoli and Søndergaard (2009) and Mihov and Santacreu (2013) to develop a small open economy model with two alternative rules: an IRR and an ERR. The small open economy, which is also the domestic economy, is modeled explicitly. The foreign economy is assumed to be exogenous (foreign output, inflation, and interest rates follow an $\operatorname{AR}(1)$ process).

In the small open economy, there is a representative consumer who chooses consumption, labor, and savings subject to a standard budget constraint. There is external habit in consumption, as explained in the previous section: Consumers care about their consumption relative to a subsistence level. Markets are complete, and consumers have access to a complete set of contingent securities that are traded internationally.

In this economy, consumption is an aggregate of both domestic and foreign goods (i.e., imports). There is home bias in consumption, which determines the degree of openness of 
the economy. Consumers choose optimally how much to consume of each domestic and foreign good.

On the production side, each good is produced by a monopolistically competitive firm that uses labor according to a constant returns-to-scale production function. Production of goods is subject to an aggregate productivity shock, which is the only source of uncertainty in this economy. Firms take as given the demand by the final producer and set a price that is a constant markup over their marginal cost. In this model, prices are sticky à la Calvo. In each period, a constant fraction of firms set prices optimally, and the rest set the price from the previous period. This results in a forward-looking process for inflation: Inflation today depends on the output gap and expected future inflation. The model is closed with an international risk-sharing condition that (i) results from the assumption of complete markets and (ii) determines a relationship between the domestic and foreign interest rates and the expected rate of depreciation of the currency.

The central bank chooses a monetary policy instrument to react to fluctuations in inflation and the output gap, which in this model is defined as the difference between actual output and the output that would be obtained if prices were flexible. Consider, as before, two cases for the monetary policy rule: (i) a rule in which the monetary authority sets the interest rate and lets the exchange rate adjust with the international risk-sharing condition that arises from the assumption of complete markets (IRR), and (ii) a rule in which the monetary authority sets the exchange rate and lets the nominal interest rate adjust through the international risk-sharing condition (ERR). In this model, and to be more consistent with the rule actually followed by the monetary authority, I assume some degree of interest rate smoothing for an IRR and some degree of exchange rate smoothing for an ERR. That is, the rules are modeled as follows:

(i) IRR

$$
i_{t}=\rho i_{t-1}+(1-\rho)\left(\phi_{y}\left(y_{t}-y^{*}\right)+\phi_{\pi}\left(\pi_{t}-\pi^{*}\right)\right),
$$

where $\rho \in(0,1)$ is the degree of interest rate smoothing.

(ii) ERR

$$
\Delta e_{t}^{*}=\overline{\Delta e}-\phi_{y}^{e}\left(y_{t}-y^{*}\right)-\phi_{\pi}^{e}\left(\pi_{t}-\pi^{*}\right)
$$

where $\overline{\Delta e}$ is the depreciation required to reach the long-run equilibrium nominal exchange rate. ${ }^{8}$ I assume some smoothing in how the nominal exchange rate adjusts to its target level:

$$
\Delta e_{t}=\left(1-\rho_{e}\right) \Delta e_{t}^{*}+\rho_{e} \Delta e_{t-1} .
$$

In contrast to the endowment economy in which I could obtain an analytical solution to capture fluctuations in the risk premium - and, hence, deviations from UIP-the production economy model has to be simulated. Mihov and Santacreu (2013) solve the model using a third-order approximation and compute second moments for the variables that the monetary authority cares about: domestic inflation, consumer price index (CPI) inflation, and output. 


\section{Table 4}

Second Moments: Production Economy

\begin{tabular}{lcc} 
Variables & IRR & ERR \\
\hline Output & 0.867 & 0.681 \\
Consumption & 0.054 & 0.044 \\
\hline Output gap & 0.823 & 0.656 \\
Domestic inflation & 1.181 & 0.611 \\
Depreciation rate & 0.497 & 0.192 \\
CPI inflation & 0.912 & 0.391 \\
Risk premium & $1.09 \mathrm{e}-03$ & $7.83 \mathrm{e}-05$ \\
\hline
\end{tabular}

\section{Quantitative Results}

Table 4 reports second moments of several economic variables and the risk premiums for the two alternative rules. The ERR generates lower volatility in the economy for both nominal and real variables. By smoothing the fluctuations in the nominal exchange rate, the central bank achieves lower volatility in both domestic inflation and CPI inflation, which also takes into account the inflation of prices for foreign intermediate goods. The main difference between this rule and one in which the exchange rate is fixed to the currency of another country (i.e., pegged) is as follows: Because a central bank that follows an ERR also reacts to fluctuations in real variables, such as the output gap, it can achieve less volatile nominal variables without increasing the volatility of real variables, as would happen with a peg. Output, consumption, and the output gap are less volatile with an ERR than with an IRR.

There are two reasons for the lower volatility: First, the actual implementation of the rule is important. In the model, the exchange rate today is predetermined, and the central bank announces the depreciation rate from time $t$ to $t+1$. This implies, for example, that the model may not feature the standard overshooting result because the monetary authority determines the currency rate both today and at $t+1$. Second, deviations from UIP are important. One way to measure these deviations in the model is by computing the volatility of the implied risk premium, which as Table 4 shows, is lower for an ERR than for an IRR.

\section{CONCLUSION}

Analyzing the properties of alternative monetary policy rules is important from a welfare perspective. In this article, I study the impact of an ERR on the volatility of both nominal and real variables. Simulations of a production economy show that the ERR is more effective in achieving lower economic volatility than a standard IRR. There are two reasons for this: (i) The actual implementation of the policy matters, since the ERR avoids the overshooting in the nominal exchange rate, and (ii) the risk premium that generates deviations from UIP is less volatile with an ERR. Moreover, the ERR performs better than a peg, since the monetary 
authority achieves exchange rate stability without relinquishing its ability to react to fluctuations of the economy.

I have incorporated several key issues in my analysis here. For instance, the credibility of the central bank is important for a policy such as the ERR to be successful and avoid large fluctuations in the nominal exchange rate. For a country with large capital inflows, lack of credibility in the monetary policy regime could trigger speculative attacks on the currency. Furthermore, the monetary authority's ability to adjust the exchange rate requires the authority to hold sufficient foreign reserves on its balance sheet. I have also abstracted from balancesheet effects. Finally, the initial net foreign asset position of the country (whether it has a surplus or a deficit) matters for the performance of the rules that attempt to stabilize the nominal exchange rate. I leave these issues for future analysis on this topic.

\section{NOTES}

1 The Federal Reserve's mandates are "maximum employment, stable prices, and moderate long-term interest rates... [with] inflation at the rate of 2 percent" (year-on-year inflation of personal consumption expenditures, or PCE; see Board of Governors of the Federal Reserve System, 2014). Moreover, the euro area mandate is "[t]o maintain price stability is the primary objective of the Eurosystem and of the single monetary policy for which it is responsible" (European Central Bank). And "The Bank of Japan, as the central bank of Japan, decides and implements monetary policy with the aim of maintaining price stability" (Bank of Japan).

2 See Taylor (1993) for reference.

3 In its April 2015 monetary policy statement, the MAS announced: "MAS will therefore continue with the policy of a modest and gradual appreciation of the S\$NEER [Singapore dollar nominal effective exchange rate] policy band. However, the slope of the policy band will be reduced, with no change to its width and the level at which it is centered. This measured adjustment to the policy stance is consistent with the more benign inflation outlook in 2015 and appropriate for ensuring medium-term price stability in the economy" (Monetary Authority of Singapore, 2015).

4 The reaction function estimation is for Singapore with the sample period 1981:Q1-2012:Q4. Instrumental variable estimation with four lags of inflation and four lags of output gap is used to instrument for future inflation and the future output gap. See Mihov (2013) for more information.

5 Under log-normality, $\log \left(\mathbb{E}_{t}\left[M_{t, t+1}\right]\right)=\mathbb{E}_{t}\left[\log \left(M_{t, t+1}\right)\right]+\frac{1}{2} \operatorname{Var}_{t}\left[\log \left(M_{t, t+1}\right)\right]$.

6 The details of this derivation are provided in Mihov and Santacreu (2013).

7 Along these simulation exercises, I set $\phi_{\pi}^{I R R}=\phi_{\pi}^{E R R}=1.5$ and $\phi_{c}^{I R R}=\phi_{c}^{E R R}=0.5$ to make the two rules consistent. However, Mihov and Santacreu (2013) find that the ERR still outperforms the IRR for different values of the coefficients of the rules.

8 I follow the convention that an increase in the exchange rate implies depreciation of the domestic currency.

\section{REFERENCES}

Abel, Andrew B. "Asset Prices under Habit Formation and Catching Up with the Joneses." American Economic Review Papers and Proceedings of the Hundred and Second Annual Meeting of the American Economic Association, May 1990, 80(2), pp. 38-42.

Alvarez, Fernando; Atkeson, Andrew and Kehoe, Patrick J. "If Exchange Rates Are Random Walks, Then Almost Everything We Say About Monetary Policy Is Wrong." American Economic Review Papers and Proceedings, May 2007, 97(2), pp. 339-45.

Alvarez, Fernando; Atkeson, Andrew and Kehoe, Patrick J. "Time-Varying Risk, Interest Rates, and Exchange Rates in General Equilibrium." Review of Economic Studies, July 2009, 76(3), pp. 851-78. 


\section{Santacreu}

Backus, David K.; Gavazzoni, Federico; Telmer, Christopher and Zin, Stanley E. "Monetary Policy and the Uncovered Interest Rate Parity Puzzle." NBER Working Paper No. 16218, National Bureau of Economic Research, July 2010; http://www.nber.org/papers/w16218.pdf.

Bank of Japan. "Outline of Monetary Policy." http://www.boj.or.jp/en/mopo/outline/index.htm/; accessed March 2, 2015.

Benigno, Gianluca; Benigno, Pierpaolo and Nisticò, Salvatore. "Second-Order Approximation of Dynamic Models with Time-Varying Risk." Journal of Economic Dynamics and Control, July 2013, 37(7), pp. 1231-47.

Benigno, Pierpaolo. "Price Stability with Imperfect Financial Integration." Journal of Money, Credit, and Banking, February 2009, 41(Suppl. s1), pp. 121-49.

Board of Governors of the Federal Reserve System. "What Are the Federal Reserve's Objectives in Conducting Monetary Policy?" Current FAQs, September 19, 2014; http://www.federalreserve.gov/faqs/money_12848.htm.

De Paoli, Bianca. "Monetary Policy Welfare in a Small Open Economy." Journal of International Economics, February 2009, 77(1), pp. 11-22.

De Paoli, Bianca and Søndergaard, Jens. "Foreign Exchange Rate Risk in a Small Open Economy." Working Paper 365, Bank of England, March 2009;

http://www.bankofengland.co.uk/research/Documents/workingpapers/2009/wp365.pdf.

European Central Bank. "Objective of Monetary Policy." https://www.ecb.europa.eu/mopo/intro/objective/html/index.en.html; accessed March 2, 2015.

Fama, Eugene F. "Forward and Spot Exchange Rates." Journal of Monetary Economics, November 1984, 14(3), pp. 319-38.

Mihov, llian. "The Exchange Rate as an Instrument of Monetary Policy." Monetary Authority of Singapore Macroeconomic Review, April 2013, 12(1), pp. 74-82.

Mihov, Ilian and Santacreu, Ana Maria. "Exchange Rates as an Instrument of Monetary Policy." Unpublished manuscript, June 2013.

Monetary Authority of Singapore. "MAS Monetary Policy Statement." January 28, 2015; http://www.mas.gov.sg/News-and-Publications/Speeches-and-Monetary-Policy-Statements/Monetary-PolicyStatements/2015/Monetary-Policy-Statement-28Jan15.aspx.

Monetary Authority of Singapore. "Monetary Policy." Undated; http://www.sgs.gov.sg/The-SGS-Market/Monetary-Policy.aspx; accessed March 9, 2015.

Parrado, Eric. "Singapore's Unique Monetary Policy: How Does It Work?" IMF Working Paper 04/10, International Monetary Fund, January 2004; http://www.imf.org/external/pubs/ft/wp/2004/wp0410.pdf.

Schmitt-Grohé, Stephanie and Uribe, Martin. "Pegs and Pain." NBER Working Paper No. 16847, National Bureau of Economic Research, March 2011; http://www.nber.org/papers/w16847.pdf.

Svensson, Lars E.O. "Open-Economy Inflation Targeting." Journal of International Economics, February 2000, 50(1), pp. 155-83.

Taylor, John B. “Discretion Versus Policy Rules in Practice." Carnegie-Rochester Conference Series on Public Policy, December 1993, 39, pp. 195-214.

Verdelhan, Adrien. "A Habit-Based Explanation of the Exchange Rate Risk Premium." Journal of Finance, February 2010, 65(1), pp. 123-46. 